\title{
Looking for Love in All the Wrong Places: Mythology of DWYL in the Neoliberal Marketplace of Academic Labour
}

Natalie Coulter

York University

\begin{abstract}
I
THOUGHT I WAS LUCKY when I landed my first contract academic faculty (CAF) position right after I finished my comprehensive exams for my doctorate. That was twelve years ago. Like many others, I thought this was the beginning of a long line of employment that would eventually land me in a tenure-track job. I loved my job as a teacher and a researcher. I was doing what I loved, and I figured that this love would carry me through to a full-time career. This was not necessarily a naive point of view, as many of my CAF colleagues were doing just that. But in the past twelve years there has been a radical shift in the academic labour market. Not only are there a small number of tenure stream, or regular academic faculty (RAF), positions, there are so many contract academic faculty that even securing enough courses every semester to pay the rent is becoming a precarious situation. There are too many CAF fighting over too few crumbs, and for some the only recourse to ensure a livelihood is to formally grieve when the crumbs don't come one's way, a situation that further alienates RAF from CAF.

But love was not enough. Doing what I loved would still leave me in a precarious position every year and constantly under the threat of being bounced from my courses with every new hire, curriculum review, or
\end{abstract}

$E S C$ 40.4 (December 2014): 13-16 
Natalie Coulter

was a long time CAF and has recently become RAF at York University's Department of Communication Studies. She hosts a CAF Facebook page committed to the issues of contract labour. Her research interests are in girls' studies, critical advertising studies, and the media of children and young people. Her book Tweening the Girl:

The Crystallization of the Tween Market has been published by Peter Lang's Mediated Youth series. She has published in the Canadian Journal of Communication, Jeunesse, and Popular Communication. teaching overload of an RAF that the department undertook. My feelings resonated with Miya Tokumitsu's article "In the Name of Love," originally published in the Jacobin, 13 January 2014, and reprinted in Slate two days later. In the article, Tokumitsu shreds the DWYL (doing what you love) mantra, arguing that it actually works to reinforce exploitation and functions as "the most perfect ideological tool of capitalism."

The mythology of DWYL is deeply entrenched in academia. Choosing to continue in school instead of entering the labour market immediately after high school, then choosing to take the valuable asset of an undergraduate education and go back into academia instead of entering the open labour market where one could (in theory) make much more money, is underpinned by the romantic notions of academic labour as being fulfilling beyond its monetary compensation. But, as Tokumitsu points out, the DWYL rhetoric has a dark side; it works to legitimate the divide of academic labour between RAF and CAF by individualizing the realities of academic labour as "loving work." This mythology is embedded through the academic system and functions to hide the structural conditions that value $\mathrm{PhD}$ labour for the graduate student but not for the graduated student on the job market.

First, DWYL is a tool to justify exploitation and devalue labour. Only certain jobs are ascribed a DWYL; there is little DWYL rhetoric to justify the labour of accountants or CEOS who are allowed to be motivated by compensation packages and not passion. Instead DWYL functions as a means to extract cheap or free labour by making certain types of work "feel like non work" (Tokumitsu). DWYL is the middle-class version of the "it's better than nothing" rhetoric that is used to justify the meager wages of the working poor. These are stories told by capitalism to justify the existence of precarious, poorly paid jobs that are structurally designed to lock workers in.

DWYL locks workers into the academic piecework of CAF by deflecting attention away from the real problem. Implied in the DWYL rhetoric is that one gets stuck in a CAF position, never winning an RAF job, because one didn't love the profession enough to get the prestigious grant or the right venue for publication that would have made the difference in the job market. What is erased from this debate is a dialogue on how the structures of universities have shifted to rely on precarious, "just in time" academic piecework as their main labour force. In the neoliberal marketplace, DWYL shifts the conversation away from structural realities to individual deficits.

Secondly, with DWYL we can ask, What is to love? DWYL divides the lovable labour from the unlovable labour. Think about what is lovable in

14 | Coulter 
an academic career. It is the autonomy and the temporal flow of work. It is about being able to teach small seminar classes that allow us to discuss and digest materials. It is about being able to pursue one's individual research passion and spend time doing the research, networking with fellow researchers and engaging in conversations pertaining to research (preferably in exotic locales). Contract faculty are alienated from this labour; instead they provide the heavy lifting of teaching. They often teach the large classes, the courses with heavy marking loads and inexperienced TAs. They often teach the courses that the RAF do not want, only finding out about these courses at the last minute. Any autonomy that they may have gained in their daily work life is lost by continual process of having to look for a job while being in a job. And they are given virtually no resources to conduct their own research. While many CAF do conduct extensive research and have impressive publication records, it is mostly done on their own time and their own dime.

The question then remains, what can be done to change this situation beyond dismantling the DWYL mythology? The first thing is to recognize the work that is being done and to label the worker with the appropriate term of "faculty" instead of "staff," "sessional," or "adjunct," terms implying that their labour is distinctly different from RAF work. We need to embrace the term faculty as part of the job title. CAF need to be labeled as faculty with the only distinction being the type of contract, not the type of work.

We also need to come clean about CAF work as work. It is not a passion or some kind of hobby that we are lucky enough to extend into a work week. It is work and labour that is precarious as well as exploitative and tenuous. As part of this discussion we need RAF to become allies not enemies. CAF are the canaries in the coalmine. Just think, if universities can illustrate that good, effective, quality teaching can be done by a precarious workforce that doesn't have tenure then what is the real value of tenure? The whole system starts to crumble.

The education continues to our students and their parents. They need to know who is really doing the labour of teaching. Who exactly are students paying for-and more importantly what exactly are they are paying for-if little of their tuition goes to the wages of their instructors? ${ }^{1} \mathrm{New}$ student recruits should be regularly asking every university they are considering applying to the ratio of courses that are taught by RAF and CAF. This education needs to continue to CAF who should inform their students,

1 Many have critiqued the growth of management and administrators. According to the Huffington Post the number of non-academic administrative and professional employees at U.S. universities has more than doubled in the past 
preferably on the course syllabus, that the course is taught by a CAF, and let them know the implications of this for the student's education.

Finally, we need to push the issue beyond the small isolated panels and discussions that are taking place now. There are great opportunities to link up as a national organization similar to what is happening in the U.S. right now with the organization the "New Faculty Majority," for example. Congress would be a good meeting point. There are a few associations, ACCUTE being one of them, that have CAF representatives. It should be mandatory that every association has a designated CAF rep, and these reps should meet as a group on an annual basis. We also need to push professional institutions like CAUT to take us more seriously and to acknowledge that CAF are not failed academics but an exploited, precarious labour force that meets the universities' neoliberal "just in time" model of delivering courses.

So do I love my job? Sure. But it is hard work, it is precarious work, and it is academic piecework. People love to sew but no one wants to make coats at home for 12 cents a coat for twelve hours a day.

\section{Works Cited}

Marcus, Jon. "Boom in Higher Ed Administrators. Huffington Post. 2 February 2014. Web. 24 October 2014.

Mihalyfy, David Francis. "Higher Education's Aristocrats." The Jacobin 15-16 (September 2014). Web. 24. October 2014.

Tokumitsu, Miya. "In the Name of Love". The Jacobin 13 (January 2014). Web. 22 September 2014.

We Teach Laurier. "November 13." weteachlaurier.tumblr.com. Tumblr. 13 November 2013. Web. 22 September 2014.

Woodhouse, Alexander Ervin Howard. "The Elephant in the Room; Or, Students Bear the Cost of the Corporate University." Rabble.ca. 25 June 2014. Web. 24 October 2014.

twenty-five years, far outpacing student growth (Marcus). At the University of Chicago senior administrators' salaries have increased between 45 percent and 135 percent in the past five years (Mihalyfy). In Canadian universities, since 2000 , there has been a 10.9 percent increase in student enrolment, 11.6 percent in faculty, and 104.5 percent in administration (Woodhouse). Wilfrid Laurier University is a good example of this. It has increased its management by 44 percent in the past four years (We Teach Laurier).

16 | Coulter 